\title{
Redefining liberty: is natural inability a legitimate constraint of liberty?
}

\author{
Zahra Ladan
}

The University of Manchester Faculty of Medical and Human Sciences, Manchester, UK

\section{Correspondence to}

Zahra Ladan, The University of Manchester Faculty of Medical and Human Sciences, Manchester M13 9PL, UK; zahraladan2@gmail.com

Received 4 July 2020 Revised 31 August 2020 Accepted 4 September 2020 Published Online First 1 October 2020
Check for updates

(c) Author(s) (or their employer(s)) 2021. No commercial re-use. See rights and permissions. Published by BMJ.

To cite: Ladan $\mathrm{Z}$. J Med Ethics 2021;47:59-62.

\section{ABSTRACT}

In P v Cheshire West, Lady Hale stated that an act that would deprive an able-bodied or able-minded person of their liberty would do the same to a mentally or physically disabled person. Throughout the judgement, there is no definition of what liberty is, which makes defining an act that would deprive a person of it difficult. Ideas of liberty are described in terms of political liberty within a society, the state of being free from external influence and individual autonomy. This essay explores various philosophical ideas of liberty and what a legitimate constraint of liberty is. It will be argued that defining liberty in terms external influence from other human agents undermines the impact of natural inability on a person's ability to fulfil their intrinsic desires-a true constraint of liberty is any which prohibits a person from acting in the way they desire. If liberty is not the same for all, it follows that a deprivation of liberty differs between different agents. Although the government must protect personal liberty, it is important to recognise that an act that may deprive an able-bodied or minded person of their liberty, may in fact promote the liberty of a disabled persons. It will be argued that acts that allow a disabled person to act out desires that they ordinarily would not be able to perform, do not deprive them of their liberty.

\section{INTRODUCTION}

Liberty, or freedom, within a society has long since been the subject of analysis from both philosophical and legal academics. In the Supreme Court judgement of P v Cheshire West, ${ }^{1}$ Lady Hale makes the following statement:

'as it seems to me, what it means to be deprived of liberty must be the same for everyone, whether or not they have physical or mental disabilities. If it would be a deprivation of my liberty to be obliged to live in a particular place, subject to constant monitoring and control, only allowed out with close supervision, and unable to move away without permission even if an opportunity became available, then it must also be a deprivation of the liberty of a disabled person'. ${ }^{1}$

In Lady Hale's view, an act that would deprive an able-minded and able-bodied person of their liberty would do the same for a disabled person. Before answering the difficult question of what it means to deprive one of their liberty, we must first define liberty itself. How can we begin to understand how a person can be deprived of their liberty, if we do not first define not only what liberty is, but also why it is a protected human right? Through analysis of philosophical literature, it will be argued that natural inability deprives one of their personal liberty and is a legitimate restraint on individual freedom. From this viewpoint, it can be argued that an act that would deprive an able-bodied and ableminded person of their liberty, may in fact promote the liberty of a disabled person.

\section{IDEAS OF LIBERTY}

Ideas of liberty are vast and varied, with the only consistent element being that individuals should, to some extent, be free within a society. The variance comes in finding how individuals can exercise that freedom and how far this freedom can extend without interference from the government. Both Miller and Berlin identified various categories of views of liberty which overlap with one another. ${ }^{23}$ The former believes that there are three 'families of ideas'; the first is the Republican idea-a person is free when they are a member of a self-governing political community. They are not just a passive member in this society, but play an active role such that the actions of the government reflect the views of the individuals that it governs over. The second view is that of the liberal-a person is free to the extent to which he can act as he wishes without interference or constraint by other agents. The final family relates to individual autonomy. The idealist idea finds that a person is free when he follows his desires and acts on his rational beliefs. [2 p.2-4] Miller himself attempts to define liberty by incorporating each of these families into one allencompassing statement-he states:

'to be genuinely free, a person must live under social and political arrangements that he has helped to make (republican); he must enjoy an extensive sphere within which he is not subject to constraint (liberal); and he must decide himself how he is to live, not borrow his ideas from others (idealist)'.[2 p19-20]

Taking Miller's stance on liberty, each family of liberty can exist among one another and one is not more favourable than the others. Each of these components is relevant to the political freedom of a society, in addition to the political liberty of the individuals that make up that society.[2 p6-7]

Berlin argues that there are two distinct aspects of liberty-negative freedom and positive freedom. Unlike Miller, who believes that all three of his 'families' of liberty contribute equally to true liberty, Berlin strongly favours one of his notions over the other. Negative liberty, according to Berlin, refers to freedom from interference or constraint. ${ }^{3}$ This notion of liberty considers the same ideals as those that Miller would identify as liberal. Those who argue in favour of negative liberty disagree on what they consider to be a true constraint of liberty. 
In reference to disabled persons, is there an argument for natural inability, that is, mental or physical disability, being a source of interference or constraint on a person's liberty? Conversely, positive freedom regards a person's ability to act in the way that they desire; to be their own master. Berlin identifies that the true self is free, in the positive sense, when they are part of a larger collective which acts to gain a higher level of freedom for all members of that community. ${ }^{3}$ Thus, Berlin's positive sense of freedom encompasses both the idealist and republican ideas discussed by Miller. It is not necessary to argue in favour of positive or negative liberty here. Instead, we seek to determine whether natural inability has an impact on liberty in either sense.

\section{CONSTRAINTS OF NEGATIVE FREEDOM}

According to Berlin, '[1]iberty in this sense is simply the area within which a man can act unobstructed by others'.[3 p.169] He finds that where a man is being interfered with to the extent that he is not able to conduct himself in the way that he desires, he is being coerced and is therefore unfree. A crucial component of coercion is that the interfering act must be done by another human agent. Negative freedom is typically discussed in terms of the external forces put on a person by another human agent. This means that internal forces that could negatively impact a man's ability to act in a certain way have no effect on his individual liberty. Consequently, natural incapacity or inability, in Berlin's opinion, cannot diminish a man of his liberty, even if it limits his ability to act in a certain way. Berlin instead finds that natural inabilities are 'conditions of liberty', as they impact the way a man utilises his liberty. ${ }^{4}$ Berlin's idea of negative liberty is echoed in $\mathrm{P} v$ Cheshire West. Despite Lady Hale not making a clear statement, we are given some insight into how the courts choose to define liberty. Lord Kerr, who agreed with Lady Hale and Lord Neuberger, stated:

\section{'liberty means the state or condition of being free from external constraint. It is predominantly an objective state. It does not depend on one's disposition to exploit one's freedom. Nor is it diminished by one's lack of capacity'. ${ }^{1}$}

Defenders of negative freedom do little to dispute Berlin's claim that liberty can only be interfered with by other agents. However, Berlin has been criticised by Miller for not providing his readers with clarity in characterising coercion and interference. Miller questions whether an interfering act must be deliberate for it to truly coerce a man and thereby diminish his liberty. He believes that moral responsibility is the key factor that must be present for an interfering act to truly impact the liberty of a man. He defines a true constraint of freedom as those which 'other human beings can be held morally responsible, either because they have created them, deliberately or negligently, or because they have failed to remove them, despite having an obligation to do so'.[2 p17] For this reason, we cannot find cause to say that natural inability is a constraint of a person's negative liberty, as the state, or any another person, has an no obligation to remove it. F A Hayek, another defender of liberal liberty, explained and defined coercion in terms of its effect on the will of a man-one is said to be coerced when his actions reflect the will of another man. ${ }^{5}$

There is a distinct issue with defining freedom in terms of coercion or moral responsibility. For Berlin, an act of coercion is a deliberate intervention. By this definition, Steiner identifies that offers and threats would too be considered coercion as they modify the way in which an agent decides to partake in an action. It follows logically that forcing the action of a man, by way of a threat, is a legitimate means of depriving him of his liberty. Conversely, there are few who could argue that making a man an offer impacts his negative liberty, despite an offer being a deliberate act, made by a human agent, that interferes with the actions of that man. This, by definition, would be considered coercion, and therefore, have a negative impact on individual liberty. The only difference between a threat and an offer is, what Steiner calls, the compliance and non-compliance consequences. He, therefore, claims that there is no effective difference in the way in which threats, but not offers, diminish the personal liberty of a man. ${ }^{6}$ Moreover, neither are truly able to diminish personal liberty as 'intervention does not count as prevention'.[6 p134] From Steiner's analysis, we can see that intervention, whether deliberate or unintentional, should not be considered a legitimate constraint of liberty. He further states:

\begin{abstract}
'The condition under which an individual is maximally unfree, is that in which another individual controls his voluntary nervous system and thereby renders it impossible for him to dispose of the various parts of his body in a manner appropriate to the doing of any action whatever'.[6 p139]
\end{abstract}

Steiner rightly acknowledges that liberty, at least in the physical sense, should be attributed to the factual question of whether an action of a man has been truly inhibited and not whether his actions have been made difficult or interfered with. Steiner emphasises the way in which a human can use his body parts and voluntary nervous system in the manner he wishes. However, his theorem is dependent on the act of another human agent, like Berlin. I question whether this is necessary. If a man is unfree when he is unable to operate and control his body, it should not matter whether he is unable to do so because of another agent or another factor. It is being argued that personal liberty of a man is deprived or diminished when any factor has made it impossible for him to operate his limbs or act in the way he wishes. It does not matter whether the preventing element is due to external factors, such as another human or internal factors, such as natural inability or disability. Henceforth, natural inability is a legitimate constraint of liberty.

Philippe Van Parijs makes a similar argument as he believes that internal factors are relevant in the discussion of constraints of liberty. He finds that '[p]ersonal abilities or talents are internal to the person, and it is therefore correct to say that it is possible for freedom, on this conception, to be restricted by internal as well as external obstacles'. ' Van Parijs critiques Hayek, and others who take the classic liberal view of freedom, because they do not consider opportunity to be a key component of 'real freedom'. Any factor that would restrict one's opportunity to act in a certain way is just as relevant to his freedom as an external obstacle forced on him from another man. ${ }^{7}$ For a man to be free and have maximum liberty, he must be in a state where he is free from external obstacles but also be in possession of the appropriate internal capabilities which provide a man with the opportunity to act in the way he wishes. This category of views is referred to as 'ability based', in contrast to the views of Hayek or Berlin which are known as 'restraint based'. Van Parijs correctly acknowledges that freedom must be considered in a broader sense that includes natural inability. In saying that natural inability is a legitimate constraint of liberty, we could in turn argue that the overall individual liberty of those who are in a permanent state of disability is at any and all times lower than the overall individual liberty of their able-bodied counterparts. 


\section{GOVERNMENT SECURITY VERSUS INDIVIDUAL LIBERTY}

In Storck v Germany, it was held that Article 5 provides a 'positive obligation on the State to protect the liberty of its citizens'. This obligation obviously requires some state intervention. This contradicts the classic liberal definition of liberty, which argues that liberty is the state in which a person is free from intervention. Therefore, there is a battle between security, provided by the state, and individual liberty and it is for the state to strike a balance between the two. This dichotomy is explained by Miller:

'In the liberal view, government secures freedom by protecting each person from the interference of others, but it also threatens freedom by itself imposing laws and directives backed up by the threat of force $[\ldots]$ the liberal tends to see freedom as beginning where politics ends'.[2 p3]

There is a distinct lack of mention of the right to security that Article 5 protects in $\mathrm{P}$ v Cheshire West. Lady Hale does briefly give mention to the duty of the state to make 'reasonable accommodation to cater to for the special needs of those with disabilities'. ${ }^{1}$ However, this does not give much indication of how far this duty extends, especially as it pertains to disabled persons.

John Stuart Mill recognises the importance of individual liberty within a society; he finds that 'no society in which libert[y] (is) not, on the whole, respected, is free, whatever may be its form of government'.[10 p55] His view of liberty is classically liberal, but also has elements of the idealist ideals. The characteristics Mill associates with individuality, which is essential within a society, are self-realisation and self-government. These are aspects that Berlin would tie to positive liberty. Mill finds that within a free society, the state may only exercise its power to prevent harm to other members of society-'the liberty of the individual must thus far be limited; he must not make himself a nuisance to other people'.[10 p101] Berlin, like Mill, argues that there must some form of regulation within a civil society, because without it, society falls into chaos. ${ }^{3}$ There is little dispute to Mill's claim that liberty should be limited where the actions of one man impact the actions of another. A state which is maximally free in the negative sense seems desirable, we must acknowledge that individuals and their actions do not live in a vacuum. I agree with Mill in that I too argue for individuality and liberal freedom, but there must some government interference for society to function. But there must also be a 'minimum area of personal freedom which must on no account be violated'.[3 p171]

So, where the actions of one man encroach into the personal sphere of freedom of another, the government may justifiably limit his liberty. But what of those whose actions impact themselves in a negative way and cause themselves harm; what role, if any, does the government play here?

Berlin has critiqued Mill for putting too much emphasis on freedom and liberty. Mill believes liberty to be of a higher importance. Berlin believes his theory is too concerned with the minimum area of control but not the sense of self-government which drives a person's ability to exercise their liberty. ${ }^{3}$ When Berlin writes about positive liberty, he speaks of a higher-self and lower-self; one is free to the extent to which he can control his immediate desires (the lower-self), by way of self-realisation and self-government (the higher-self). ${ }^{3}$ To Mill, it is the role of the society to help those who lack self-government to develop their individuality through education and thereby exercise their liberty. ${ }^{10}$

Taylor finds the main issue with Mill's the notion of negative liberty is the lack of recognition for self-realisation. ${ }^{11}$ This echoes
Berlin's critique of Mill. Taylor advocates for the idealist view of freedom such that 'one is only free to the extent that one has effectively determined oneself and the shape of one's life'.[11 p143] He finds that part of self-realisation is understanding what is important to each individual and their motivation to be free. Taylor correctly acknowledges that humans have many intrinsic desires which become more and less significant at different times in our lives. Freedom is one of these intrinsic desires, but it is not necessarily the most significant and therefore does not take precedent over all others. ${ }^{11}$

The government has a moral duty to protect those who are unable to self-govern. For those with mental or physical disability, could we argue that by interfering with their actions we are in fact promoting their liberty? What if we are giving them the physical means to live out their desires in a way that they ordinarily would not have been able to? We have established that natural inability is a constraint of liberty. It could, therefore, be argued that by interfering with a person, we are attempting to recompensate them for the personal liberty they have lost as a result of their natural inability. In $\mathrm{Re} A$ and $C,{ }^{12}$ this argument was used by the C's legal team. The case concerned two people with Smith Magenis Syndrome, a child, A, and a young person who lacked capacity, C. This genetic condition presents as aggression, self-injurious behaviour, and severe sleep disturbance. For their safety, their parents had decided that during the night, it was best to lock their children's bedroom doors to stop them from putting themselves in dangerous situations. Justice Munby had to determine whether these circumstances constituted a deprivation of liberty. He summarised the submission made by C's counsel:

\begin{abstract}
'She says such restrictions are needed because of specific features of C's genetic condition, to help her lead the best life she can. C's parents, she says, are looking after her, not punishing her; promoting and improving her autonomy and dignity, not restricting them; and in supporting her as they do they are giving to her, not taking away. ${ }^{12}$
\end{abstract}

Munby J rightly praised these statements and therefore held that in the case of $C$ there was no deprivation of liberty. ${ }^{12}$ In the Court of Appeal judgement of $\mathrm{P}_{\mathrm{v}}$ Cheshire West, it is noteworthy that Lord Justice Munby was in agreeance with the judgement of Re A and C. Similar to Van Parijis, he rightly acknowledges the impact of natural inability on one's opportunity to exercise their personal liberty and moreover, identified that ' $[\mathrm{w}]$ hat may be a deprivation of liberty for one person may not be for another'. ${ }^{13}$ In direct reference to $\mathrm{P}$, he stated:

'Because of his disabilities, $\mathrm{P}$ is inherently restricted in the kind of life he can lead. P's life [...] is dictated by his disabilities and difficulties'. ${ }^{13}$

Despite this legitimate analysis, the Supreme Court dismissed Munby's judgement-it was determined that this undermined the universal nature of human rights. ${ }^{1}$ However, I would argue the opposite. Acknowledging that those with natural inability at all times have less individual liberty than their able-bodied counterparts does not undermine the human rights of this population, but instead highlights the injustice. Thus, the government should go further to ensure the liberty of disabled persons.

To Berlin, there is no justification in saying that one is promoting a person's positive liberty by interfering with their negative liberty. He states: 
'Liberty may have to be curtailed to make room for other good things, security or peace, or health [...] but to curtail freedom is not to provide it, and compulsion, no matter how well justified, is compulsion and not liberty'.[14 p285]

These other goods, such as health, are independent of liberty and by promoting the former, you cannot promote the latter. Although overall good is being done, we cannot say it is being done for the sake of liberty. He finds that this is the issue with positive liberty as it allows for dictators to justify their actions by saying they are acting to promote the overall freedom of a society. ${ }^{3}$ While there is merit in applying this philosophy to a whole society, the same cannot be said for disabled persons. Primarily, it is being argued that natural inability is a legitimate constraint on liberty, thus persons with disability have a lower baseline liberty than their able-bodied counterparts. Henceforth, a person that interacts and interferes with the actions of disabled persons can promote their liberty if they are aiding them to act in the way they desire.

\section{CONCLUSION}

To define liberty in terms of the actions of another human agent dismisses the impact of natural inability on individual liberty. A constraint of liberty should be considered legitimate when it makes it impossible for an individual to act in the way they wish. By analysing a constraint in this way, natural inability is a true constraint of liberty. It has been argued that ability-based views of liberty are favourable, as they acknowledge that one's ability to exercise their liberty is dependent on opportunity. Security from the government must be balanced with individual liberty, but it is important to acknowledge that liberty is not always more important than other intrinsic values. Lady Hale's analysis of a deprivation of liberty has put too much focus on liberty and fails to acknowledge these other intrinsic values.

Acknowledgements I would like to thank Neil Allen (University of Manchester) for providing general supervision.

Contributors ZL wrote this essay in its entirety.

Funding The authors have not declared a specific grant for this research from any funding agency in the public, commercial or not-for-profit sectors.

Competing interests None declared.

Patient consent for publication Not required.

Provenance and peer review Not commissioned; externally peer reviewed.

Data availability statement No data are available. Not applicable.

\section{ORCID iD}

Zahra Ladan http://orcid.org/0000-0002-1456-9906

\section{REFERENCES}

1 P v Cheshire West [2014] UKSC 19.

2 Miller D. Introduction. Liberty: Oxford University Press, 1991.

3 Berlin I. Hardy H, ed. Two concepts of liberty. Oxford: Oxford University Press, 2002.

4 Berlin I, Margalit A, Ullmann-Margalit E. Margalit A, Ullmann-Margalit E, eds. Isaiah Berlin: a celebration. The Hogarth Press Ltd, 1991.

5 von Hayek FA. Miller D, ed. Freedom and coercion. Liberty, Oxford: Oxford University Press, 1991.

6 Steiner H. Miller D, ed. Individual liberty. Liberty, Oxford: Oxford University Press, 1991.

7 van Parijs P. Real freedom for all: what (if anything) can justify capitalism? Oxford: Oxford University Press, 1997.

8 Schmidt AT. An unresolved problem: freedom across lifetimes. Philos Stud 2017;174(6):1413-38.

9 Storck v Germany (2005) 43 EHRR 96.

10 Mill JS. Alexander E, ed. On liberty. Ontario: Broadview Press, 1999.

11 Taylor C. Miller D, ed. What's wrong with negative liberty. Liberty, Oxford: Oxford University Press, 1991.

$12 \operatorname{Re} A$ and C [2010] EWHC 978 (Fam).

13 Cheshire West and Chester Council v P [2011] EWCA Civ 1257.

14 Berlin I. Hardy H, ed. Liberty. Oxford: Oxford University Press, 2002. 